\title{
New records of Galictis vittata (Schreber, 1776) for the western slope of the Andes, Pacific region of Colombia
}

\author{
Jonard David Echavarria-Renteria ${ }^{1 *}$, Alex Mauricio Jiménez-Ortega², and Leison Palacios-Mosquera ${ }^{2}$ \\ ${ }^{1} 1$ Grupo de Investigación Manejo y Gestión de la Vida Silvestre del Chocoana, Facultad de Ciencias Naturales, Programa de \\ Biología, Universidad Tecnológica del Choco, Carrera 22 No. 18B - 10, Quibdó, Chocó, 270002, Colombia. Email: jd07echavarria@ \\ hotmail.com (JDER), alexmauriciojimenez@gmail.com (AMJO), lepamo8@gmail.com (LPM). \\ ${ }^{*}$ Corresponding author
}

Galictis vittata (Greater Grison) is distributed from Mexico through Central and South America down to northern Argentina and southern Brazil, from sea level up to 1,500 masl. In Colombia, this species is widely distributed along the Caribbean and Andean regions, and to a lesser extent in the Orinoquia and Pacific regions. Specimens of G. vittata were fortuitously captured in the municipality of Quibdó. This finding, along with an observation in the municipality of Rio Quito and a literature survey in international databases and published records of the species, were used to draw a map of current localities of the species in our country. A new record of $G$. vittata is reported for Colombia based on two voucher specimens deposited in the Colección Teriológica del Chocó. These specimens correspond to two females, one adult and one juvenile preserved as skins. This finding is the fourth report of the species from the western Andean zone of Colombia in the Pacific Region and the first for the Department of Chocó. It is a significant addition to the geographical and ecological distribution of G. vittata in the Choco, a region currently facing various diversity and conservation issues that threaten its survival, such as loss of habitat and changes of land use.

Galictis vittata (hurón o grisón mayor) se distribuye en la parte norte de América Latina, desde México a través de Centro y Suramérica, hasta el norte de Argentina y el sur de Brasil desde el nivel del mar hasta los 1,500 m, ocurriendo con más frecuencia por debajo de $500 \mathrm{~m}$. En Colombia, esta especie presenta una amplia distribución a lo largo del Caribe, los Andes y, en menor proporción, en las regiones de la Orinoquía y Pacífica. Especímenes de G. vittata fueron obtenidos de manera ocasional en el municipio de Quibdó, estos junto a una observación obtenida en el municipio de Río Quito, más la revisión de la información disponible en bases de datos internacionales y registros publicados de la especie en la literatura fueron usados para alimentar un mapa de localidades actual de la especie en nuestro país. Se reporta un nuevo registro de $G$. vittata para Colombia, basado en dos especímenes testigos, depositados en la Colección Teriológica del Chocó. Los especímenes de G. vittata corresponden a dos hembras, una adulta y otra juvenil preservados como piel. Este hallazgo, constituye el cuarto reporte de la especie para el occidente de los Andes de Colombia en la Región Pacífica y el primero para el departamento del Chocó, el cual representa una adición significativa en la distribución geográfica y ecológica de este taxón en la región del Chocó, donde su diversidad enfrenta problemas de conservación por factores que amenaza su supervivencia, como la pérdida de hábitat y la transformación en el uso de la tierra.

Keywords: Colombia; greater grison; Pacific region.

๔ 2018 Asociación Mexicana de Mastozoología, www.mastozoologiamexicana.org

\section{Introduction}

The genus Galictis belongs to the family Mustelidae and groups together a number of species distributed throughout tropical and subtropical areas of North America, including two species: G. cuja (Molina 1782) and G. vittata (1776) sensu Wozencraft Schreber (2005) and Bornholdt et al. (2013). Galictis cuja (lesser grison) is distributed in southern Latin America, from the southern tip of Peru, southern Bolivia and northeastern Brazil to southern Chile and Argentina (Yensen and Tarifa 2003; Cuaron et al. 2008; Bornholdt et al. 2013). G.vittata (greater grison) thrives across the northern part of Latin America, from Mexico through Central and South America down to northern Argentina and southern Brazil, from sea level up to 1,500 masl, being more abundant at altitudes below 500 masl (Timm et al. 1989; Yensen and Tarifa 2003; Cuaron et al. 2008; Monjeau et al. 2009; Bornholdt et al. 2013).

In Colombia, the great grison (G. vittata) has been recorded for the Caribbean, the Andes and the Orinoquía (Solari et al. 2013); unconfirmed references are also available for the Amazon, such as Alberico et al. (2000), and
Muñoz-Saba and Alberico (2004). According to current lists of mammals for the country, this species inhabits the Caribbean region in the Departments of Atlántico, Bolívar, Cesar, Córdoba, La Guajira (Jimenez-Alvarado et al. 2016), Magdalena and Sucre (Cuervo et al. 1986; Alberico et al. 2000; Solari et al. 2013). In the Andean region, it has been reported in the Departments of Antioquia, Cundinamarca, Caldas and northern Santander (Castaño 2012; Solari et al. 2013; Jimenez-Alvarado et al. 2016); in Orinoquía, in the Departments of Casanare, Meta and Vichada (Alberico et al. 2000; Solari et al. 2013). In the Pacific region, in the Departments of Cauca (Alberico et al. 2000; Ramírez-Chaves and Perez 2011) and Nariño (Ramírez-Chaves and Noguera-Urbano 2010, Figure 1). However, despite of this broad range, no accurate information is currently available about its ecology, distribution and conservation status (González-Maya et al. 2011 Calderon-Capote et al. 2015; Jimenez-Alvarado et al.2016).

Jimenez-Alvarado et al. (2016) report the existence of 161 documents related to G. vittata in Colombia. A detailed revision detected an error in this figure, as according to 
the information reported by these authors, the total number of references adds up to only 157 documents. Of this, 78 records correspond to the Colombian Caribbean, with 54 new records for this region, which is one of the most important approximations to the distribution of $G$. vittata in northern Colombia. However, besides the references just mentioned, 38 additional mentions for the Colombian territory are available, making a total of 195 recounts. Of these, $58.5 \%(n=114)$ correspond to references in interviews; 27.7 $\%(n=54)$, direct observations; $9.2 \%(n=18)$, specimens in scientific collection; and $4.6 \%(n=9)$, photographic records. Of all records, $86.2 \%$ were considered to be poorly reliable (interviews and observations), while the remaining $13.8 \%$ were deemed high reliable, corresponding to photographs and collection specimens. The few mentions for the Colombian Pacific region are reliable, as these refer to geo-referenced evidence on the presence of the species related to collection specimens and photographic records.

Recent studies (Escobar-Lasso and Guzman-Hernández 2014; Jimenez-Alvarado et al. 2016) confirm that there are few specimens deposited in Colombian scientific collections. A total of 18 specimens are currently recorded in collections, distributed in the Institute of Natural Sciences at Universidad Nacional de Colombia (ICN), the Museum of Natural History at Universidad del Cauca (MHNC), the Collection of Mammals at Instituto Alexander von Humboldt (IAvH-M), the Collection of Mammals at Universidad del Valle (CM-VC), and the Museum of Natural History at Universidad de Caldas, Manizales-Colombia (MHN-UC), in addition to some international museums in the U.S., including the Field Museum of Natural History, Chicago (FMNH), the National Museum of Natural History, the Smithsonian Institution (USNM), and the American Museum of Natural History (AMNH, Table 1).

From this study, the Collection of Mammals of Chocó at Universidad Tecnológica del Chocó (CMCH) is also included as having specimens of $G$. vittata from the Pacific region of Colombia. Furthermore, data were obtained about the presence of this species in our country from the Global
Biodiversity Information Facility database (GBIF; http:// data.gbif.org), and from literature records of the species that, together with the records reported herein, were used to elaborate a map of the current distribution of G. bittata in Colombia using all record localities; data involving location inconsistencies were excluded. A layer of the national system of natural parks (PNN) was used as an input in this map in order to identify the populations covered by protected areas in our country.

New Records of Great Grison for the Central Biogeographic Chocó: The material reported herein for the western Cordillera of the Andes, specifically in the Department of Chocó, was obtained incidentally in the vicinity of a farm located in the district of Flores de Buenaños, municipality of Quibdó ( $5^{\circ} 40^{\prime} 55.2^{\prime \prime} \mathrm{N},-76^{\circ} 38^{\prime} 27.6^{\prime \prime} \mathrm{W} 54$ masl). Two female specimens of $G$. vittata were hunted by dogs on a farm (apparently in the early morning hours), leading to their immediate death; these specimens were recovered by the farm owner and delivered to S. Mosquera-Mosquera on 6 August 2012 (Figure 1). An additional record refers to an observation on October 2014 (Figure 2) by E. Yair CuestaRíos at the juristiction of La Soledad, municipality of Rio Quito (532' $17.11^{\prime \prime} \mathrm{N},-76^{\circ} 46^{\prime} 47.34^{\prime \prime} \mathrm{W}, 55$ masl).

The two Quibdó specimens were prepared and preserved following the protocol of Vargas-Sandoval (1994) and deposited in the Collection of Mammals of Chocó at Universidad Tecnológica del Chocó $(\mathrm{CMCH})$ under collection numbers $\mathrm{CMCH003011} \mathrm{and} \mathrm{CMCH003012.} \mathrm{The} \mathrm{speci-}$ mens collected match the descriptions of the species by Yensen and Tarifa (2003) and Tirira (2007), including short legs, slender body, small and flattened head exhibiting a diagonal stripe that reaches the shoulders, grayish dorsum, short and thick tail, and a long neck. The measurements of the specimens as based on skins are shown in Table 2; the skulls of these specimens are currently missing.

These new records of $G$. vittata confirm the presence of the species in the Pacific region of Colombia, approximately $85 \mathrm{~km}$ west from the nearest record in the Department of

Table 1. Complete list of localities of Galictis vittata in Colombia, based on data from the literature and international museums. *International collections.

\begin{tabular}{|c|c|c|c|c|c|}
\hline Specimen & Department & Municipality/Locality & Coordinates & Reference & Quantity \\
\hline IAvH-M- 5459, 5547 & Sucre & Colosó/Ricaurte & $9.5-75.35$ & \multirow{3}{*}{$\begin{array}{l}\text { Collection of Mammals at Instituto Alexander von Humboldt } \\
(\text { IAvH-M) }\end{array}$} & \multirow{3}{*}{4} \\
\hline IAvH-M-3111 & Magdalena & Santa Marta/PN Tayrona & - & & \\
\hline IAvH-M- 5381 & Meta & - & - & & \\
\hline ICN 1423 & & Villavicencio & $4.141-73.626$ & \multirow{3}{*}{$\begin{array}{l}\text { Institute of Natural Sciences at Universidad Nacional de Colombia } \\
\text { (ICN) }\end{array}$} & \multirow{3}{*}{3} \\
\hline ICN1894 & & Restrepo & $4.1584-73.444$ & & \\
\hline ICN 9925 & Cauca & El Tambo & $2.437-76.8133$ & & \\
\hline CM-VC 08105, 08106 & Vichada & Puerto Carreño & $5.775-68.184$ & Collection of Mammals at Universidad del Valle (CM-VC) & 2 \\
\hline CMCH 003011 & \multirow[t]{2}{*}{ Chocó } & Quibdó & $6.682-76.641$ & \multirow{2}{*}{$\begin{array}{l}\text { Choco Teriologica Collection at Universidad Tecnológica del } \\
\text { Chocó }(\mathrm{CMCH})\end{array}$} & \multirow[t]{2}{*}{2} \\
\hline CMCH 003012 & & Rio Quito & $5.538-76.779$ & & \\
\hline MHN-UC 1156 & Caldas & Marquetalia & $5.2905-75.007$ & $\begin{array}{l}\text { Collection of Mammals at the Museum of Natural History, } \\
\text { Universidad de Caldas, Manizales - Colombia (MHN-UC) }\end{array}$ & 1 \\
\hline FMNH 68906 & Sucre & Colosó/Ricaurte & $9.5-75.35$ & Field Museum of Natural History, Chicago-EE.UU (FMNH)* & 2 \\
\hline USNM 544420 & Sucre & Sitio Nuevo /La Trinidad & $10.851-74.6188$ & $\begin{array}{l}\text { National Museum of Natural History, the Smithsonian Institution } \\
\text { (USNM)* }\end{array}$ & 2 \\
\hline AMNH-142246 & Meta & Villavicencio & - & American Museum of Natural History $(\mathrm{AMNH})^{*}$ & 2 \\
\hline
\end{tabular}




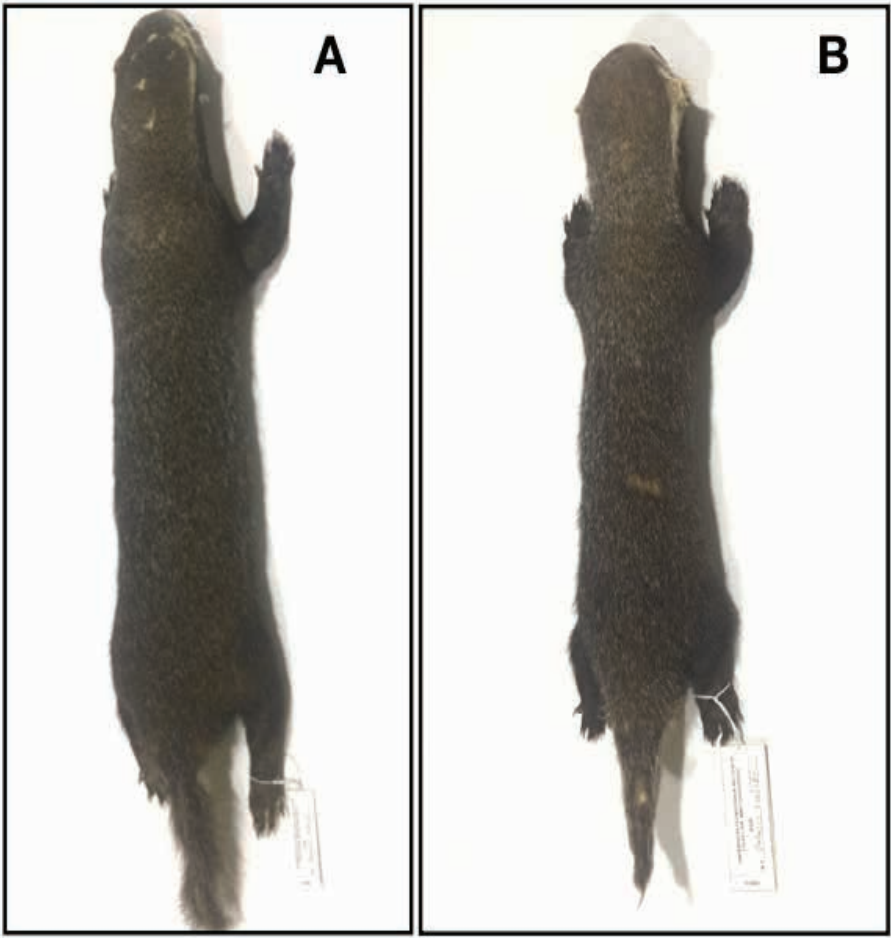

Figure 1. Specimens of $\mathrm{G}$. vittata $(\mathrm{A}=\mathrm{CMCH} 00301$, adult female; $\mathrm{B}=\mathrm{CMCH} 003012$, juvenile female), collected at Flores de Buenanos, municipality of Quibdó.

Antioquia, and $360 \mathrm{~km}$ north of the record in the Department of Cauca, in addition to confirming the presence of this species in the Department of Chocó (Figure 3). Nonetheless, its presence in this area was expected, given the ecological continuity of the landscape and the Chocoano tropical forest between southwestern Colombia and northwestern Ecuador (Tirira 2008); in addition, this species has been recorded previously by Handley (1966) as G. allamandi in the Darien-Panamá region at the northwest end of the Biogeographic Chocó.

Furthermore, Asprilla-Perea et al. (2013) mention the presence of G.vittata in the Department of Chocó, based on a lot of specimens confiscated by Corporación Autónoma Regional para el Desarrollo Sostenible del Chocó (Regional Autonomous Corporation for the Sustainable Development of Chocó, CODECHOCO); although the original site of capture of that individual was not established. Thus, the
Table 2. External measurements of the specimens of $G$. vittata recorded in the municipality of Quibdó, Department of Chocó, Colombia

\begin{tabular}{lllll}
\hline Measurements & $\begin{array}{l}\text { CMCH003011 } \\
(\mathrm{mm})\end{array}$ & $\begin{array}{l}\text { CMCH003012 } \\
(\text { Juvenil) } \\
(\mathrm{mm})\end{array}$ & $\begin{array}{l}\text { Yensen and Tarifa } \\
(2003)\end{array}$ & $\begin{array}{l}\text { T i r i r a } \\
(2007)\end{array}$ \\
\hline LT & 680 & 427 & $600-760$ & $600-747$ \\
LC & 153 & 94 & $135-195$ & $135-195$ \\
LCC & 525 & 340 & $450-600$ & $450-600$ \\
LP & 80 & 47 & - & $66-97$ \\
LO & 23 & 16 & $20-32$ & $20-32$ \\
\hline
\end{tabular}

LT: total length; LC: tail length; LCC: head-body length; LP: foot length; LO: ear length.

records reported here are remarkable because they fill the information gap in the distribution range of the species, for being located in an area representative of the ChocóManabí conservation corridor and the most important strip in terms of the conservation hotspot or the of TumbesChocó Magdalena Priority Terrestrial Ecoregion (ETP). It is worth stressing that this region had not been previously considered within the known distribution of the species, either by Solari et al. (2013) or by Jimenez-Alvarado et al. (2016), although Muñoz-Saba and Alberico (2004) did mention the presence of the species from observations (without reporting the precise locality) in the municipality of Tumaco, while Ramírez-Chaves and Noguera-Urbano (2010) confirmed its presence at La Cruz, jurisdiction of Plazuelas, Department of Nariño. This record in the region suggests that the tropical rain forest (bp-T) located in the central area of the Biogeographic Choco of Colombia should be included within the habitats of the species, in addition to those already described by other researchers (e. g., Yensen and Tarifa 2003; Tirira 2008; Bornholdt et al. 2013).

There is currently scarce information about the biology, ecology and distribution of this rare species (G. vittata) in Colombia (Calderon-Capote et al. 2015). As it is rarely observed, it has been listed as a priority species in the research of small carnivores in Colombia (González-Maya et al. 2011; Suarez-Castro and Ramirez-Chaves 2015). The profound transformation of natural ecosystems in Colombia - particularly in the Pacific region currently under deg-
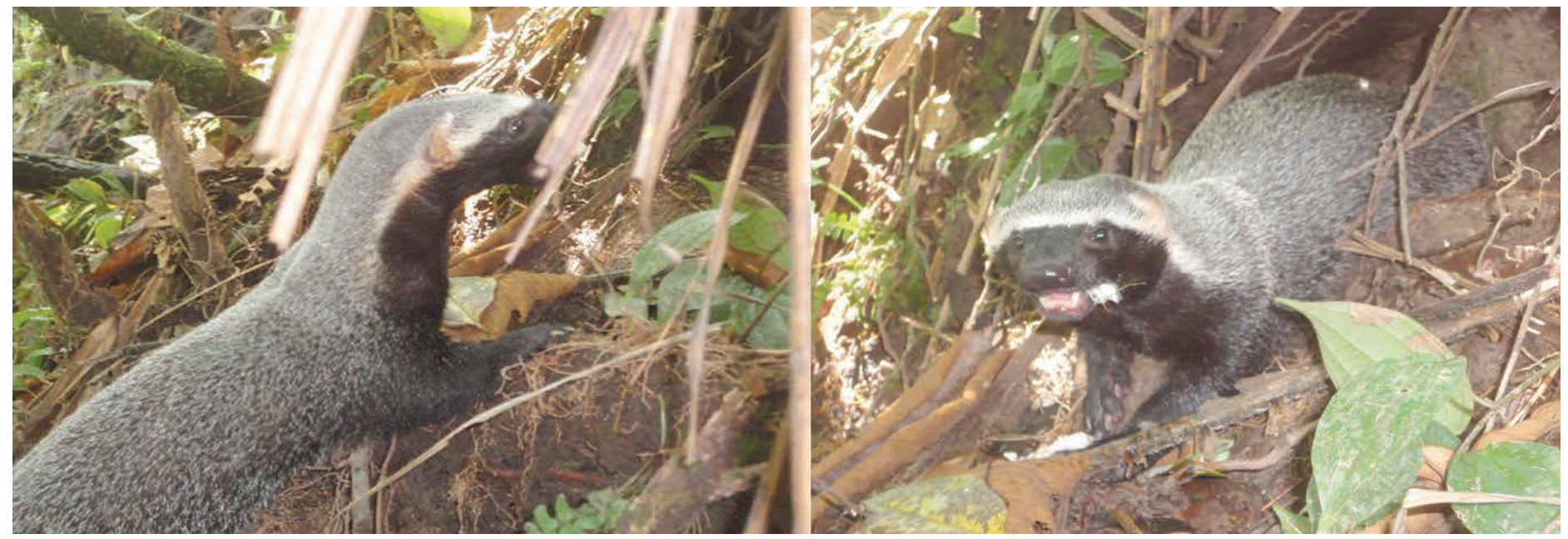

Figure 2. Photographic record of G. vittata in the jurisdiction of La Soledad, municipality of Rio Quito (Photographs: Eric Yair Cuesta Ríos). 


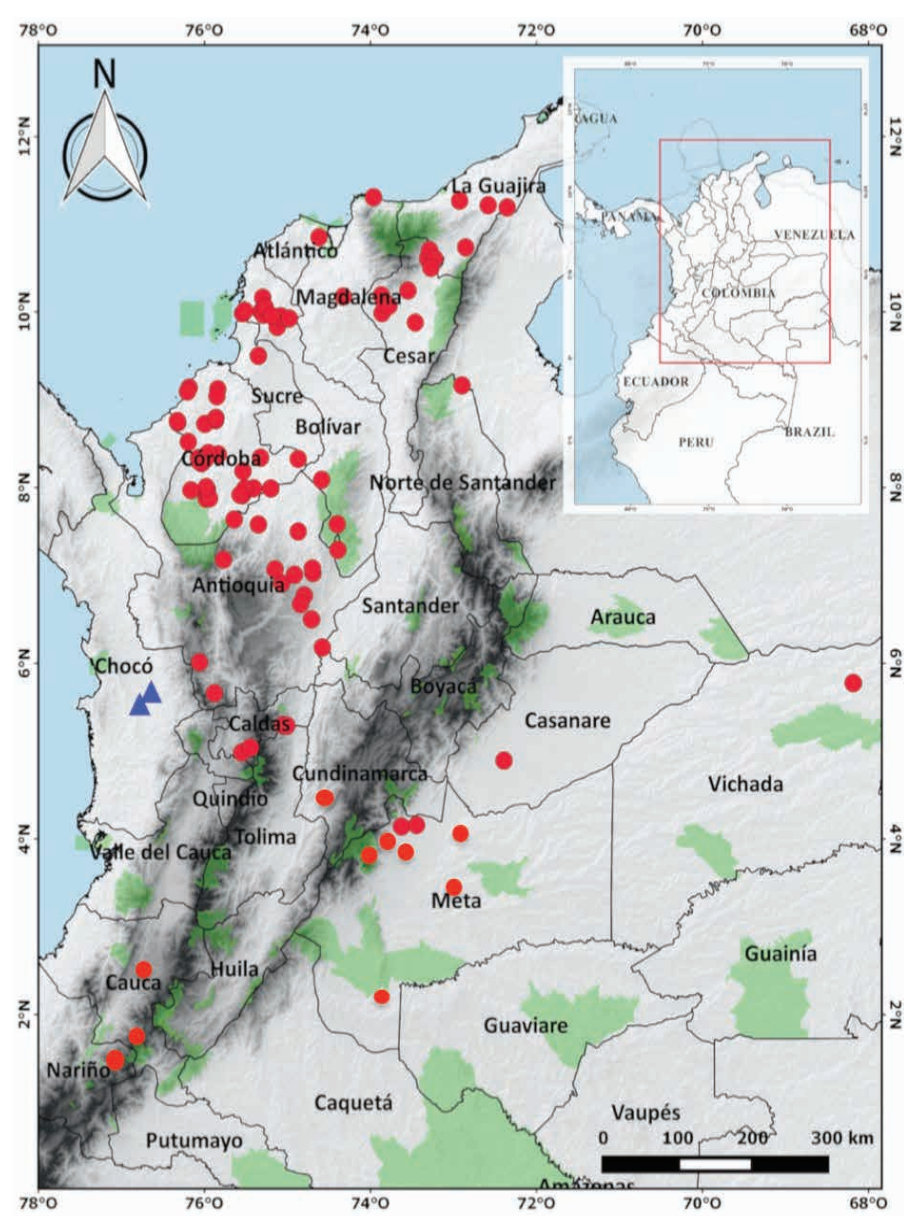

Figure 3. Geographical location of records of G. vittata in Colombia: Red circles = records in GBIF (http://data.gbif.org), ICN, MHNC, or in the literature: Escobar-Lasso and Guzmán-Hernández, (2014), Jiménez-Alvarado et al. (2016). Blue triangles = New records for the Pacific region of Colombia reported here. Green = System of Natural Parks.

radation processes due to open-pit gold and platinum mining, wood logging, hunting and the Tumbes crop system - have all converted the original forest into a number of landscapes, becoming a factor that affects this species and jeopardizes the viability of its local populations.

According to our map, this species is currently located outside the conservation areas in the National System of National Parks (PNN, Figure 1). Ecological macro-analyses involving mammals of the Biogeographic Chocó (e. g., Mantilla-Meluk and Jimenez-Ortega 2006) suggest the creation of a conservation area in the Chocó central area, a proposal that we support, as it is one of the most suitable areas for the conservation of this and other species. G. vittata is likely covered by the protected areas of Colombia; however, further sampling is required to confirm its presence in those areas to preserve its populations. This species is considered as threatened with extinction in Costa Rica (Timm et al. 1989) due to the loss of habitats through deforestation; its preservation in this country is regulated by the Law on Wildlife Conservation No. 7317, the Organic Law of the Environment No. 7554, and the Decree No. 26435-MINAE. In Belize, G. vittata is protected by the Law of Wildlife Protection, and in Nicaragua, hunting of this species is prohibited (Fuller et al. 1987). According to the IUCN Red List, G. vittata (greater grison) is listed as Least Concern-LC (Cuarón et al. 2016), and is included in Appendix III of the Convention on International Trade in Endangered Species of Wild Fauna and Flora (CITES). However, it is not included in the list of threatened species of Colombia (Resol. 1912 of 2017).

Given the huge knowledge gap on G. vittata in Colombia, this record for the lowlands in the western Cordillera of the Andes is remarkable, as it broadens its geographic and ecological range in the Pacific region of Colombia, in addition to increasing the number of mammal species recorded for the Department of Chocó. It further highlights the importance of forest conservation in the central area of the Biogeographic Chocó to preserve the diversity of mammals distributed in this portion of the territory.

The information reported here could be used for the development of conservation plans according to databased analyses on the ecology and conservation status supplemented with distribution maps of this species in the country. This will lead to the identification of priority conservation areas, considering the intensive transformation processes of natural ecosystems in Colombia, particularly in the Colombian Pacific region (Kattan and Naranjo 2008).

\section{Acknowledgments}

The authors wish to thank the Colección Teriológica del Chocó (ColTeChoco Teriologica) for allowing us access to it; to Universidad Tecnológica del Choco "Diego Luis Córdoba" for being an institution that supports scientific research in the Department of Chocó; to S. Mosquera Mosquera and E. Yair Cuesta-Ríos, for providing photographs and key data on specimens, to J. Quinto-Mosquera for the contributions to the taxonomy and the manuscript, and to the Research Group on Wildlife Management of the Chocó. María Elena Sánchez-Salazar translated the manuscript into English.

\section{Literature Cited}

Alberico, M., A. Cadena., J. Hernández-Camacho, and Y. Muñoz-Saba. 2000. Mamíferos (Synapsida: Theria) de Colombia. Biota Colombiana 1: 3-75.

Asprilla-Perea, J., J. E. Serna-Agudelo, and Y. Palacios-Asprilla. 2013. Diagnóstico sobre el decomiso de fauna silvestre en el departamento del Chocó (Pacífico Norte colombiano). Revista UDCA Actualidad \& Divulgación Científica 16:175-184.

Bornholdt, R., K. Helgen, K. Klaus-Peter., L. Oliveira, M. Lucherini, AND E. EIZIRIK. 2013. Taxonomic revision of the genus Galictis (Carnivora: Mustelidae): species delimitation, morphological diagnosis, y refined mapping of geographical distribution. Zoological Journal of the Linnean Society 167:449-472.

Calderón-Capote, M. C., A. V. Rojas-Rojas., C. Cárdenas-González, and A. Pardo-Ramírez. 2015. Familia Mustelidae. Pp. 110-133, in los carnívoros terrestres y semiacuáticos continentales de Colombia: Guía de Campo (Suárez-Castro, A. F., and H. E. Ramírez-Chaves, eds.). Universidad Nacional de Colombia. Bogotá, Colombia.

CAstaño, J. H. 2012. Mamíferos de Caldas: un análisis de vacíos de información. Boletín Científico Museo de Historia Natural Universidad de Caldas 16:101-119. 
Cuarón, A. D., A. Morales., A. Shedden., E. Rodríguez-Luna., P. C. De Grammont, and L. Cortés-Ortiz. 2008. Ateles geoffroyi. The IUCN Red List of Threatened Species. Fecha de consulta 07/03/2017 En http://dx.doi.org/10.2305/IUCN.UK.2008.RLTS. T2279A9387270.en

Cuarón, A. D., F. Reid, And K. Helgen. 2016. Galictis vittata. The IUCN Red List of Threatened Species 2016: e.T41640A45211961. http://dx.doi.org/10.2305/IUCN.UK.2016-1.RLTS.T41640 A45211961.en. Downloaded on 24 February 2018.

Cuervo-Díaz, A., J. I. Hernández-Camacho, and A. Cadena. 1986. Lista actualizada de los mamíferos de Colombia: anotaciones sobre su distribución. Caldasia 15:471-501.

Escobar-Lasso, S., and C. F. Guzmán-Hernández. 2014. El registro de mayor altitud del Hurón Mayor Galictis vittata, con notas sobre su presencia y conservación dentro del departamento de Caldas, en la región andina de Colombia. Therya 5:567-574.

Fuller, K. S., B. Swift., A. Jorgenson., A. Brautigam, and A. L. GASKI. 1987. Latin American wildlife trade laws. Second edition, with 1987 update. World Wildlife Fund. Washington, U. S. A.

González-Maya, J. F., A. A. Cepeda-Mercado., J. L. Da Belant., S. Zárrate-Charry., A. Balaguera-Reina, and A. Rodríguez-Bolaños. 2011. Research priorities for the small carnivores of Colombia. Small Carnivore Conservation 44:7-13.

Handley, C. O., JR . 1966. A synopsis of the genus Kogia (pygmy sperm whales). Pages 62-69 in Whales, dolphins, and porpoises (Norris, K. S., ed.). University of California Press, Los Angeles, U.S. A.

Jiménez-Alvarado, S. J., A. A. Ocampo., A. Pineda-Guerrero., D. A. Zárrate-Charry., I. M. Vela-Vargas., J. Chacón-Pacheco, and J. F. GonzÁlez MaYA. 2016. Analysis of the distribution of the Grison (Galictis vittata) (Carnivora: Mustelidae) in the Colombian Caribbean. Therya 7:179-186.

Kattan, G. H., and L.G. Naranjo. 2008. Regiones biodiversas: herramientas para la planificación de sistemas regionales de áreas protegidas. Fundación EcoAndina, WCSColombia, WWF-Colombia. Cali, Colombia.

Mantilla-Meluk, H., and A. M. Jiménez-Ortega. 2006. Estado de Conservación y algunas consideraciones biogeográficas sobre la quirópterofauna del Chocó Biogeográfico Colombiano. Revista Institucional. Universidad Tecnológica del Chocó Diego Luís Córdoba 25:10-17.

MolinA, G. I. 1782. Saggio sulla storia naturale del Chili. Stamperia di Sto. Tommaso d'Aquino. Bologna, Italy.

Monjeau, J. A., J. A. Tort., J. Márquez., P. Jayat., B. N. Palmer-Fry., S. D. Nazar-Anchorena., A. D. Vincenzo, And J. Polop. 2009. Latitudinal patterns of species richness distribution in South American carnivores. Mastozoología Neotropical 16:1-14.

Muñoz-Saba, Y., ANd M. Alberico. 2004. Mamíferos en el Chocó biogeográfico. Pp. 559-598 in Diversidad Biótica IV. El Chocó Biogeográfico/Costa Pacífica (Rangel-Ch. J. O., ed.). Instituto de Ciencias Naturales, Universidad Nacional, Bogotá. Colombia.

Ramírez-Chaves H.E., AND E. A. Noguera-Urbano. 2010. Lista preliminar de los mamíferos (Mammalia: Theria) del departamento de Nariño, Colombia Biota Colombiana 11:117-140.

Ramírez-Chaves H. E., and W. A. Pérez. 2011. Mamíferos (Mammalia: Theria) del departamento del Cauca, Colombia. Biota Colombiana 11:147-171.
SChreber, J. C. D. 1776. Die Saügthiere in Abbildungen nach der Natur mit Beschreibungen. Wolfgang Walther, Erlangen, Germany, Part III 18:313-328.

Solari, S., Y. Muñoz-Saba, J. V., Rodríguez-Mahecha., T. Defler, H. E. Ramírez-Chaves, and F. Trujlllo. 2013. Riqueza, endemismo y conservación de los mamíferos de Colombia. Mastozoología Neotropical 20:301-365.

Suárez-Castro, A. F., and H. E. Ramírez-Chaves, eds. 2015. Los carnívoros terrestres y semiacuáticos continentales de Colombia. Guía de campo. Bogotá, Universidad Nacional de Colombia.

Timm, R. M., D. E. Wilson., B. L. Clauson., R. K. Laval, and C. S. Vaughan. 1989. Mammals of the la Selva-Braulio Carrillo complex, Costa Rica. North American Fauna 75:1-162.

TiRIRA, D. G. 2007. Mamíferos del Ecuador. Guía de campo. Ediciones Murciélago Blanco. Publicación Especial de los Mamíferos del Ecuador 6. Quito, Ecuador.

TIRIRA, D. G. 2008. Mamíferos de los bosques húmedos del Noroccidente de Ecuador. Ediciones Murciélago Blanco y Proyecto PRIMENET. Publicación Especial sobre los Mamíferos del Ecuador 7. Quito, Ecuador.

Vargas Sandoval, M. 1994. Colecta, preservación y montaje de artrópodos asociados a mamíferos silvestres. Curador Entomológico y Acarológico 1:10-12.

Wozencraft, W. C. 2005. Order Carnivora. Pp. 532-628 in Mammal Species of the World: A Taxonomic and Geographic Reference (Wilson, D. E., and D. M. Reeder, eds.). 3ra ed. The Johns Hopkins University Press. Baltimore, U. S. A.

Yensen, E., AND T. TARIFA. 2003. Galictis vittata. Mammalian Species 727:1-8.

Associated editor: Sergio Solari

Submitted: December 4, 2017; Reviewed: December 29, 2017;

Accepted:May 3, 2018; Published on line:May25, 2018. 
NEW RECORDS OF GALICTIS VITTATA

190 THERYA Vol. 9 (2): 185-189 